\title{
Effects of human versus mouse leukemia inhibitory factor on the in vitro development of bovine embryos
}

\author{
A. Rodríguez ${ }^{\text {a }}$, C. De Frutos ${ }^{\text {a }, \text { C. Díez }}{ }^{\text {a }, \text { J.N. Caamaño }}{ }^{\text {a }}$ N. Facal ${ }^{\text {a }}$, \\ P. Duque ${ }^{\mathrm{b}}$, C. García-Ochoa ${ }^{\mathrm{b}}$, E. Gómez ${ }^{\mathrm{a}, *}$ \\ a Géneticay Reproducción SERIDA, Camino de los Claveles 604, 33203 Gijón, Asturias, Spain \\ ${ }^{\mathrm{b}}$ CEFIVA Gijón, Álvarez Garaya 12, 33206 Gijón, Asturias, Spain
}

Received 15 September 2006; received in revised form 23 November 2006; accepted 29 November 2006

\begin{abstract}
Leukemia inhibitory factor (LIF) is a cytokine that shows conflicting effects on in vitro produced (IVP) bovine embryos. Bovine LIF (bLIF) has been cloned and used in culture, but there is no commercially available bLIF. Thus, researchers use human LIF (hLIF) to supplement the culture medium for bovine embryos because of its greater sequence homology compared to murine LIF (mLIF). We compared the effects of mLIF and hLIF on the development of bovine embryos in culture with the effects described for bLIF. Oocytes were matured and fertilized in vitro and cultured in modified synthetic oviduct fluid with BSA. On Day 6 postinsemination, morulae were cultured for $48 \mathrm{~h}$ in the presence of: (1) $\mathrm{mLIF}, 100 \mathrm{ng} \mathrm{ml}^{-1}$; (2) hLIF, $100 \mathrm{ng} \mathrm{ml}^{-1}$; or (3) no LIF. Reduced blastocyst rates were observed on Day 8 for hLIF at the middle and expanded stages, while mLIF had no effect. In contrast, Day 8 blastocysts showed decreased cell counts both in terms of inner cell mass (ICM) and ICM/total cell proportions in the presence of mLIF, while hLIF had no effect. No changes were seen in trophectoderm (TE) and total cell counts. The increased hatching rates and TE cell counts previously described for bLIF, together with the disparate effects exhibited by hLIF and mLIF during blastocyst formation indicate these compounds are inappropriate to replace bLIF. We recommend that heterospecific LIF should not be used to supplement the culture medium for bovine embryo or embryonic stem cells.
\end{abstract}

(C) 2006 Elsevier Inc. All rights reserved.

Keywords: Inner cell mass; Trophectoderm; Blastocyst; LIF

\section{Introduction}

Leukemia inhibitory factor (LIF) is a cytokine that is considered essential for blastocyst implantation and pregnancy maintenance [1,2]. Binding of LIF to its receptor (LIFr) forms a high affinity complex in association with the gpl30 subunit. This dimerization activates multiple signals involving cytoplasm proteins, such as those of the Jak-Stat and Shp2-Erk pathways [3]. In vitro produced (IVP) bovine embryos express LIFr and

\footnotetext{
* Corresponding author. Tel.: +34 985195300; fax: +34 985195310.

E-mail address: egomez@serida.org (E. Gómez).
}

gpl30 transcripts in all stages of preimplantation development. On the contrary, in vivo embryos do not express LIFr during blastulation, although gpl30 transcripts can be detected from the morula to the hatched blastocyst stage [4]. In vitro produced embryos express the LIF ligand at every stage analyzed [5]. During the whole culture period, concentrations of recombinant $100 \mathrm{ng} \mathrm{ml}^{-1}$ bovine LIF (bLIF) or lower have been shown to improve bovine embryonic development [6]. These effects of bLIF are observed during the second half of the culture period [7]. Despite these findings, most studies assessing the effects of LIF in bovine embryo cultures have used human LIF (hLIF), since there is no commercially available bLIF. The rationale for this is that 
the human cytokine shares greater sequence homology with bLIF than mouse LIF (mLIF) (89.1 and 76.8\%, respectively). However, the use of hLIF has yielded controversial results as compared to bLIF, and mLIF has not been used for this purpose. When added from the morula stage, hLIF has been reported to have no effect on subsequent development [8,9]. During the course of blastocyst formation, hLIF has been found to stimulate expansion and hatching [8,10], but other authors report no comparable effect [11]. It has also been described that the number of cells in the inner cell mass (ICM) and total cell numbers increase in the presence of hLIF, although this led to no improvement in pregnancy and survival rates to cryopreservation [8,9]. Recently, hLIF has been reported to have adverse effects on embryonic development kinetics, morphology, cell counts and expression of Oct4 and laminin, having no apparent influence on the subsequent formation of outgrowths [12]. In the present study, we examined the ability of mLIF and hLIF to mimic the effects described for bLIF during bovine blastocyst development.

\section{Material and methods}

All chemicals were purchased from Sigma (Madrid, Spain) unless otherwise indicated.

\subsection{Oocyte recovery}

Slaughterhouse cow ovaries were placed in $\mathrm{NaCl}$ solution $\left(9 \mathrm{mg} \mathrm{ml}^{-1}\right)$ containing antibiotics (penicillin, $100 \mathrm{IU} \mathrm{ml}^{-1}$ and streptomycin sulphate, $100 \mu \mathrm{g} \mathrm{ml}^{-1}$ ) and maintained at $30-35^{\circ} \mathrm{C}$ until recovery of COCs. Ovaries were washed twice in distilled water and once in freshly prepared saline. COCs were aspirated from 2 to $8 \mathrm{~mm}$ visible follicles through an 18-gauge needle connected to a syringe and recovered into a $50 \mathrm{ml}$ Corning tube. Follicular fluid and COCs were placed in an ovum concentrator (Em-Con, Comextrade, Tarragona, Spain) and rinsed three times in holding medium (HM) consisting of TCM199 (Invitrogen, Barcelona, Spain), $25 \mathrm{mM}$ Hepes and BSA $0.4 \mathrm{~g} \mathrm{l}^{-1}$, supplemented with $2 \mathrm{IU} \mathrm{ml} \mathrm{ml}^{-1}$ of heparin.

\subsection{In vitro maturation}

Only oocytes enclosed in a compact cumulus with an evenly granulated cytoplasm were selected for maturation. The COCs were washed three times in HM and twice in maturation medium, which consisted of bicarbonate-buffered TCM199, FSHp $\left(1 \mu \mathrm{g} \mathrm{ml}^{-1}\right)$, LH $\left(5 \mu \mathrm{g} \mathrm{ml}^{-1}\right), 17 \beta$-estradiol $\left(1 \mu \mathrm{g} \mathrm{ml}^{-1}\right)$ and $10 \%$ fetal calf serum. Maturation was performed by culturing approximately $50 \mathrm{COCs}$ in $500 \mu \mathrm{l}$ of maturation medium in four-well dishes at $39{ }^{\circ} \mathrm{C}$ in $5 \% \mathrm{CO}_{2}$ in air with high humidity for 22-24 h.

\subsection{In vitro fertilization}

Sperm separation was carried out by the swim-up procedure [13]. Briefly, semen from one frozen straw corresponding to a single bull was thawed in a water bath and added to a polystyrene tube containing $1 \mathrm{ml}$ of pre-equilibrated Sperm-TALP. After $1 \mathrm{~h}$ of incubation, approximately $700 \mu l$ of the upper layer of supernatant containing the motile sperm was removed. The sperm was centrifuged for $7 \mathrm{~min}$ at $200 \times g$ and the supernatant aspirated to leave a pellet of approximately $100 \mu \mathrm{l}$ in volume. The sperm concentration was determined with a hemocytometer. The COCs were washed twice in holding medium and placed in fourwell culture dishes containing pre-equilibrated fertilization medium (Fert-TALP) with heparin $\left(10 \mu \mathrm{g} \mathrm{ml}^{-1}\right.$, Calbiochem, La Jolla, CA). Spermatozoa were then added at a concentration of $2 \times 10^{6}$ cells ml $^{-1}$ in $500 \mu \mathrm{l}$ of medium per well containing $100 \mathrm{COCs}$ for maximum. In vitro fertilization (IVF) was accomplished by incubating oocytes and sperm cells together for $18-20 \mathrm{~h}$ at $39{ }^{\circ} \mathrm{C}$ in $5 \% \mathrm{CO}_{2}$ with high humidity.

\subsection{In vitro embryo culture}

The cumulus cells were detached using a vortex, and zygotes cultured in synthetic oviduct fluid containing amino-acids, citrate and myo-inositol, as described by Ref. [13], modified with $6 \mathrm{~g}^{-1}$ BSA and no serum (mSOF). Droplets of medium were layered under mineral oil and cultured at $39{ }^{\circ} \mathrm{C}$ in $5 \% \mathrm{CO}_{2}, 5 \% \mathrm{O}_{2}$ humidified air until $139 \mathrm{~h}$ post-insemination (Day 6). The medium was renewed on Day 3. On Day 6, morulae (with no more than $9 \%$ showing incipient cavitation) were allocated to the experimental groups and cultured for 2 days in mSOF. Treatments were as follows: (1) recombinant mLIF (L5158); (2) recombinant hLIF (L5283); (3) no LIF (negative control). The concentration of LIF used was $100 \mathrm{ng} \mathrm{ml}^{-1}$ as described in recent studies using hLIF $[8,12]$.

Embryonic development was recorded as the stages early, middle, expanded or hatched blastocyst.

\subsection{Differential cell counts}

Day 8 expanded and hatched blastocysts were fixed and stained for differential cell counting [14]. Blastocysts 
Table 1

Blastocyst development rates for bovine morulae cultured in SOFaaci $+6 \mathrm{~g} \mathrm{l}^{-1} \mathrm{BSA}$ in the presence of $100 \mathrm{ng} \mathrm{ml}^{-1}$ leukemia inhibitory factor (LIF) of mouse $(\mathrm{m})$ or human $(\mathrm{h})$ origin or with no additives (control)

\begin{tabular}{|c|c|c|c|c|c|c|c|c|}
\hline \multirow[t]{2}{*}{ Group } & \multirow[t]{2}{*}{$N$} & \multicolumn{3}{|c|}{ Day 7 blastocysts (\%) } & \multicolumn{3}{|c|}{ Day 8 blastocysts $(\%)$} & \multirow[t]{2}{*}{ Hatched } \\
\hline & & Early & Middle & Expanded & Early & Middle & Expanded & \\
\hline mLIF & 142 & $44.9 \pm 5.3$ & $31.0 \pm 3.6$ & $11.3 \pm 2.7$ & $55.4 \pm 3.6$ & $47.4 \pm 3.9$ & $32.3 \pm 3.3$ & $5.0 \pm 1.6$ \\
\hline hLIF & 141 & $42.7 \pm 5.3$ & $26.8 \pm 3.6$ & $10.2 \pm 2.7$ & $49.6 \pm 3.6$ & $42.0 \pm 3.9^{\mathrm{a}}$ & $27.2 \pm 3.3^{\mathrm{a}}$ & $3.6 \pm 1.6$ \\
\hline Control & 140 & $50.6 \pm 5.3$ & $34.3 \pm 3.6$ & $17.7 \pm 2.7$ & $62.9 \pm 3.6$ & $57.7 \pm 3.9^{\mathrm{b}}$ & $38.9 \pm 3.3^{\mathrm{b}}$ & $6.6 \pm 1.6$ \\
\hline
\end{tabular}

$N$, number of Day-6 morulae cultured. Data are LSM \pm S.E. (six replicates). Different superscripts (a and b) indicate significant difference $(p<0.05)$.

were incubated in $500 \mu \mathrm{l}$ BSA-free TCM199 Hepes (Invitrogen) with $1 \%$ Triton $\mathrm{X}-100$ and $100 \mu \mathrm{g} \mathrm{ml}^{-1}$ propidium iodide for $30 \mathrm{~s}$. Samples were then fixed in $500 \mu \mathrm{l}$ ethanol with $25 \mu \mathrm{g} \mathrm{ml}^{-1}$ bisbenzimide (Hoechst 33342) and stored overnight at $4{ }^{\circ} \mathrm{C}$. These fixed and stained blastocysts were transferred directly to a glycerol droplet on a glass microscope slide. Cell counts were made using digital images obtained with an inverted microscope equipped with a UV excitation filter at 330 $385 \mathrm{~nm}$ and a barrier filter at $420 \mathrm{~nm}$. Trophectoderm (TE) cells were identified by their red fluorescence; ICM cells appeared blue.

\subsection{Statistical analysis}

The data were analyzed in two steps. First, factors showing significant influence were identified by categorical data modeling (CATMOD) using SAS Version 8.2 software (1999; SAS Institute Inc., Cary, Inc.). The factors found to have a significant effect on the dependent variables were treatment and replicate, but not the blastocyst stage at which the cell counts were performed. Secondly, these significant factors were used to produce a linear model using the general linear models procedure (GLM; SAS software). The GLM was used to estimate the least square means (LSM) for each fixed effect having a significant $F$ value. Duncan's

Table 2

Cell counts for expanded and hatched blastocysts produced from morulae cultured in SOFaaci $+6 \mathrm{~g}^{-1} \mathrm{BSA}$ in the presence of $100 \mathrm{ng} \mathrm{ml}^{-1}$ leukemia inhibitory factor (LIF) of mouse (m) or human (h) origin or with no additives (control)

\begin{tabular}{|c|c|c|c|c|c|}
\hline \multirow[t]{2}{*}{ Group } & \multirow[t]{2}{*}{$N$} & \multicolumn{3}{|c|}{ Number of cells } & \multirow{2}{*}{$\begin{array}{l}\text { ICM/total } \\
(\%)\end{array}$} \\
\hline & & ICM & $\mathrm{TE}$ & Total & \\
\hline$n L I F$ & 22 & $19.1 \pm 3.1^{\mathrm{x}}$ & $119 \pm 7.9$ & $133 \pm 7.5$ & $13.8 \pm 2.4^{\mathrm{x}}$ \\
\hline hLIF & 19 & $29.7 \pm 3.1^{y}$ & $108 \pm$ & $134 \pm 7.5$ & $20.9 \pm 2.4^{\mathrm{y}}$ \\
\hline Control & 18 & $32.6 \pm 3.0^{y}$ & $108 \pm 7.5$ & $137 \pm 7.6$ & $24.8 \pm 2.3^{\mathrm{y}}$ \\
\hline
\end{tabular}

$N$, number of blastocysts counted. Data are LSM \pm S.E.; Different superscripts ( $\mathrm{x}$ and $\mathrm{y})$ indicate significant differences $(p<0.01)$; ICM, inner cell mass; TE, trophectoderm. multiple-range test was used to compare the raw means calculated for the main effects. Development data were transformed to frequency percentages, while blastocyst cell counts were expressed as absolute values.

\section{Results}

Table 1 shows our in vitro blastocyst development rates and indicates no differences on Day 7. On Day 8, however, rates were reduced for middle and expanded stage in the presence of hLIF, while mLIF had no effect. In contrast with these findings, Day 8 blastocysts treated with mLIF showed decreased cell counts both in terms of ICM and ICM/total cell proportions, whereas hLIF had no effect (Table 2).

\section{Discussion}

The role of hLIF in bovine embryo culture has been controversial in previous studies [8-11] in which the effects of different supplements, such as serum, synthetic molecules and BSA were examined. In the present study, embryonic development was impaired by hLIF, while the number of ICM cells was reduced by mLIF, in disagreement with the effects described by Yamanaka et al. for bLIF [6,7]. While bLIF has been described to increase TE cell counts without affecting the ICM [6,7], hLIF has been noted to increase [8,9], decrease [12] or have no effect on the ICM (present work). In addition, mLIF was found here to have no effect on the number of TE cells yet to reduce the ICM. Thus, neither hLIF nor mLIF were able to mimic the effects reported for bLIF. The detrimental effects of hLIF during embryonic development we observed are consistent with the findings of a recent report by Vejlsted et al. [12]. These disparate effects exhibited by hLIF and mLIF during blastocyst formation provide additional evidence that these compounds should not be used to replace bLIF. Indeed, this has been previously pointed out [6,7]. In mice, reduced blastocyst development and cell numbers have been attributed to 
treatment with LIF antisense nucleotides [15]. These effects and the existence of LIF mRNA in the TE and low affinity LIFr (a $190 \mathrm{kDa}$ transmembrane protein) mRNA in the ICM but not in the TE [16], suggest that TE produced, endogenous LIF can bind to the ICM. In contrast, exogenous LIF does not bind to the ICM of whole mouse embryos [17]. This issue has not been addressed in cattle, but ES-like cells have been derived using hLIF [18] in the absence of exogenous LIF [19], and the generation of cell colonies from blastomeres is not influenced by exogenous hLIF [20]. Therefore, according to the results of the present and former reports, heterospecific LIF should not be used for experiments on bovine embryos and embryonic stem cells.

\section{Acknowledgements}

The authors wish to thank Fernando García Ruiz for technical assistance and José Luis Fernández for typing the manuscript.

This study was supported by Grant AGL2005-04479 from the Spanish Ministry of Education and Science.

\section{References}

[1] Robb L, Dimitriadis E, Li R, Salamonsen LA. Leukemia inhibitory factor and interleukin-11: cytokines with key roles in implantation. J Reprod Immunol 2002;57:129-41.

[2] Lass A, Weiser W, Munafo A, Loumaye E. Leukemia inhibitory factor in human reproduction. Fertil Steril 2001;76:1091-6.

[3] Niwa $\mathrm{H}$. Molecular mechanism to maintain stem cell renewal of ES cells. Cell Struct Funct 2001;26:137-48.

[4] Eckert J, Niemann H. mRNA expression of leukaemia inhibitory factor (LIF) and its receptor subunits glycoprotein 130 and LIFreceptor-beta in bovine embryos derived in vitro or in vivo. Mol Hum Reprod 1998;4:957-65.

[5] Wrenzycki C, Herrmann D, Lucas-Hahn A, Korsawe K, Lemme E, Niemann H. Messenger RNA expression patterns in bovine embryos derived from in vitro procedures and their implications for development. Reprod Fertil Dev 2005;17:23-35.

[6] Yamanaka M, Kudo T, Kimura N, Amano T, Itagaki Y. Effect of bovine leukemia inhibitory factor on hatching and numbers of inner cell mass and trophectoderm of bovine intact and biopsied blastocysts. Anim Sci J 1999;70:444-50.
[7] Yamanaka M, Amano T, Kudo T. Effect of the presence period of bovine leukemia inhibitory factor in culture medium on the development of in vitro fertilized bovine embryos. Anim Sci J 2001;72:285-90.

[8] Sirisathien S, Hernandez-Fonseca HJ, Bosch P, Hollet BR, Lott JD, Brackett BG. Effect of leukemia inhibitory factor on bovine embryos produced in vitro under chemically defined conditions. Theriogenology 2003;59:1751-63.

[9] Funston RN, Nauta WJ, Seidel Jr GE. Culture of bovine embryos in buffalo rat liver cell-conditioned media or with leukemia inhibitory factor. J Anim Sci 1997;75:1332-6.

[10] Marquant-Le Guienne B, Humblot P, Guillon N, Thibier M. Murine LIF improves the development of IVF cultured bovine morulae. J Reprod Fertil 1999;12:61 (abs).

[11] Fukui Y, Matsuyama K. Development of in vitro matured and fertilized bovine embryos cultured in media containing human leukemia inhibitory factor. Theriogenology 1994;42:663-73.

[12] Vejlsted M, Avery B, Gjorret JO, Maddox-Hyttel P. Effect of leukemia inhibitory factor (LIF) on in vitro produced bovine embryos and their outgrowth colonies. Mol Reprod Dev 2005;70:445-54.

[13] Parrish JJ, Susko-Parrish JL, Leibifried-Ruthledge ML, Critser ES, Eyestone WH, First NL. Bovine in vitro fertilization with frozen-thawed semen. Theriogenology 1986;25:591-600.

[14] Thouas GA, Korfiatis NA, French AJ, Jones GM. Trounson AO Simplified technique for differential staining of inner cell mass and trophectoderm cells of mouse and bovine blastocysts. Reprod Biomed Online 2001;3:25-9.

[15] Cheng TC, Huang CC, Chen CI, Liu CH, Hsieh YS, Huang CY, Lee MS, Liu JY. Leukemia inhibitory factor antisense oligonucleotide inhibits the development of murine embryos at preimplantation stages. Biol Reprod 2004;70:1270-6.

[16] Nichols J, Davidson D, Taga T, Yoshida K, Chambers I, Smith A. Complementary tissue-specific expression of LIF and LIF-receptor mRNAs in early mouse embryo genesis. Mech Dev 1996;57: 123-31.

[17] Fry RC. The effect of leukemia inhibitory factor (LIF) on embryogenesis. Reprod Fertil Dev 1992;4:449-58.

[18] Saito S, Sawai K, Ugai H, Moriyasu S, Minamihashi A, Yamamoto Y, Hirayama H, Kageyama S, Pan J, Murata T, Kobayashi Y, Obata Y, Yokoyama KK. Generation of cloned calves and transgenic chimeric embryos from bovine embryonic stem-like cells. Biochem Biophys Res Commun 2003;309: 104-13.

[19] Mitalipova M, Beyhan Z, First NL. Pluripotency of bovine embryonic cell line derived from precompacting embryos. Cloning 2001;3:59-67.

[20] Rexroad Jr CE, Powell AM. Culture of blastomeres from in vitromatured, fertilized, and cultured bovine embryos. Mol Reprod Dev 1997;48:238-45. 